\title{
Os perigos da inocência: a possibilidade de um olhar filosófico sobre o filme Meu Amigo Nietzsche
}

\section{ABRAÃO LINCOLN FERREIRA COSTA ${ }^{1}$}

O curta metragem Meu amigo Nietzsche (2012) ${ }^{2}$, do diretor Fáuston da Silva, trouxe uma proposta tão feliz quanto inovadora ao cinema brasileiro. Com pouquíssimo orçamento e um elenco composto por atores amadores, o filme mostra-se de boa qualidade, conduzindo-nos a uma reflexão acerca do imensurável potencial a ser encontrado em vários livros de filosofia.

A história acontece numa cidade da periferia do Distrito Federal, quando o garoto Lucas, após a volta da escola, envolvido numa brincadeira de aparar pipa, encontra jogada num aterro de lixo próximo da sua casa a obra Assim Falava Zaratustra, do filósofo alemão Friedrich Nietzsche. A respeito dessa cena, considero não ter havido melhor modo de ter conhecido o livro, ao vermos a motivação da brincadeira infantil ocasionada pelo impulso da superação na disputa da pipa. Mesmo a partir de um ambiente desolador, os conteúdos expressam simbolicamente uma marca indelével da filosofia nietzschiana: o poder contido na criação.

Numa explícita crítica ao analfabetismo funcional, o filme mostra, de início, a dificuldade do garoto em ler as palavras - quando repreendido pela professora, era dele exigido um melhor rendimento na escola. Podemos deferir dessa exigência pedagógica a provocativa reflexão contida em Aurora, outra obra do filósofo, referente ao hábito da maioria dos homens internalizarem os desígnios da tradição sem sequer questionar a origem desses valores. Somos obrigados a seguir regras, embora quase todos nós sejamos incapazes de reconhecer os pressupostos de cada ação, no intuito de nos tornarmos aceitos por algum grupo social. Verificar a origem dessas ações para entendê-las como boas ou ruins, pouquíssimo importa - trata-se da moralidade dos costumes, daqueles que "obedecem porque obedecem" (NIETZSCHE, 2004, § 9).

Após algumas tentativas frustradas de entender ao menos o título da obra, Lucas é salvo pelo antiquíssimo recurso dramatúrgico do deus ex machine 3 . Somente com as informações valiosas do catador de papel, o garoto consegue mergulhar no magnífico, mas também perturbador, mundo filosófico-literário. Dava-se ali, assim

\footnotetext{
${ }^{1}$ Doutorando em Filosofia pela UNIOESTE e professor de filosofia pelo Centro Universitário Planalto do Distrito Federal (UNIPLAN) e da Secretaria de Estado de Educação do Distrito Federal (SEEDF).

2 Pode ser visualizado nesses endereços: https://www.youtube.com/watch?v=oC4I29w4QJs; https://www.youtube.com/watch?v=WaPDqoYHpWs;

https://www.youtube.com/watch?v=Uzjj6U51MEA;

https://www.youtube.com/watch?v=cn_78cn8gkQ.

3 Recurso dramatúrgico já utilizado na Antiguidade, que consistia originariamente na descida em cena de um deus sobre o palco com a missão de solucionar arbitrariamente um impasse vivido pelos personagens.
} 
como o ocorrido com o personagem nietzschiano Zaratustra, um processo de maturação que o levaria a uma irreversível transformação do espírito.

Se, num primeiro instante, o filme nos mostra a dificuldade vivida por um aluno da periferia, vítima do analfabetismo funcional, por outro, nos mostra sua potência elevada a um nível além do imaginado após as releituras do livro, fazendo com que ele escape do controle da escola, da família e da religião.

Caso pudermos aproximar o filme da filosofia nietzschiana, diremos que o personagem Lucas é, no decorrer da história, comparado ao processo de metamorfoseamento espiritual encontrado na primeira parte sobre "Das três metamorfoses" do Zaratrusta, quando "o espírito se torna camelo, o camelo se torna o leão e o leão se torna a criança" (NIETZSCHE, 2014, p. 27). Para entendermos essa simbologia é preciso saber que para Nietzsche o camelo significa aquele que de maneira obediente suporta o peso dos costumes, como as obrigações corriqueiras do dia a dia. Assim como qualquer outro garoto, Lucas precisou se enquadrar às determinações do mundo, exemplo disso era a obrigação de ser um bom aluno. Diferentemente do camelo, o leão se sente farto de todo o enquadramento social, por isso o segundo passo da metamorfose tem a ver com o rugido leonino da negação. Não a tudo! Embora considere relativamente difícil identificar uma negação contundente em qualquer uma das cenas, de todo modo as releituras do livro, acompanhada das indagações do garoto, despertou na mãe a suspeita de um filho que já se recusava à inserção obediente dos valores da tradição. "Mãe, Deus está morto?" pergunta não menos inocente, quanto chocante, tornando-o um sério suspeito, como qualquer outro espírito inquieto quando suspeita da origem dos seus costumes. A metamorfose se conclui no reconhecimento do protagonista de seu próprio poder criador ao despertar o espírito da criança; a criança que se descobre como criança: o desejo de se tornar um "super homem" quando crescer; a incitação aos outros meninos da escola a despertarem suas potências; o reconhecimento do amor quando dito à mãe trata-se de um sentimento para além do bem e do mal. $\mathrm{O}$ desfecho revela o amadurecimento alcançado com a leitura da obra, pois, segundo as palavras da professora: "Ele não é mais um menino. Ele é uma dinamite!".

A despeito das supostas críticas pela ousadia de aproximar o curta de um clássico da literatura alemã do século XIX, vejo na direção de Fáuston da Silva um trabalho excepcional: marcante no sentido de nos fazer pensar o quanto o ensino brasileiro nos deve, no que se refere a um convincente projeto educacional, e capaz, assim, de formar seres humanos. Sob o ensejo político, parece irresistível pensar se realmente alguma criança pode elevar-se assustadoramente através da leitura de uma obra literária encontrada num lixão. Logo, pergunto como mensurar os riscos caso houvesse escolas e bibliotecas públicas de qualidade onde livros como esse fossem mais facilmente encontrados? Depois de ver o filme, parece fazer mais sentido o motivo pelo qual alguns políticos de modo escuso se mostram 
empenhados na luta pela aprovação do PL 867 (Escola sem Partido). Certamente, não apenas pelo combate ao discurso em defesa do pluralismo de ideias nas salas de aula, mas principalmente, devido a clara preocupação com o surgimento de cidadãos mais críticos.

\section{Referências bibliográficas}

NIETZSCHE, F. W. Assim Falou Zaratustra. Trad. Paulo César de Souza. São Paulo: Companhia das Letras, 2014.

Aurora. Trad. Paulo César de Souza. São Paulo: Companhia das Letras, 2004.

MEU amigo Nietzsche. Direção: Fáuston da Silva. Brasília, 2012. Disponível em:https://www.youtube.com/watch?v=oC4I29w4QJs;

https://www.youtube.com/watch?v=WaPDqoYHpWs;

https://www.youtube.com/watch?v=Uzjj6U51MEA;

https://www.youtube.com/watch?v=cn_78cn8gkQ. Acesso em: 28. 11. 2016.

Submissão: 02.08.2016 / Aceite: 22.08.2016 